otd-nie, 1986.

[4] V. A. Solodov, E. A. Solodova, "Sistemyi s peremennyim zapazdyivaniem”, M., Nauka, 1980.

[5] L. I. Grehova, "Diskretnaya model transportnogo zapazdyivaniya: Katalog programmnyih moduley. Spetsializirovannyiy mezhotraslevoy fond algoritmov i programm. VPO «Soyuzpromavtomatika»", Kievskoe PKB ASU, K., 1983.

[6] V. A. Khobin, A. G. Pleve, S. Yu. Mitrofanov, "Modelirovanie zvena s peremennyim vremenem zapazdyivaniya na ETsVM", Ukaz. VINITI dep. rukopisi, 1985, vol. 7.

[7] A. V. Netushil, A. V. Baltrushevich, V. V. Burlyaev i dr., "Teoriya avtomaticheskogo upravleniya: Nelineynyie sistemyi upravleniya pri sluchaynyih vozdeystviyah: Ucheb. dlya vuzov”, 2-e izd., pererab. i dop., M., Vyissh. shk., 1983.

\title{
ОСОБЛИВОСТІ НАЛАШТУВАННЯ СЕD-ПРОГРАМ ДЛЯ ПІДВИЩЕННЯ ЕФЕКТИВНОСТІ МОДЕЛЮВАННЯ ВИТРАТОМІРІВ
}

\author{
Ф.Д. Матіко1, В.І. Роман², О.Я. Масняк³ \\ 1,2,3 Національний університет «Львівська політехніка», Україна \\ ORCID: ${ }^{1}$ 0000-0001-6569-2587, ${ }^{2}$ 0000-0002-8546-6752 \\ Scopus ID: ${ }^{1} 29068004100$ \\ E-mail: ${ }^{1}$ fmatiko@gmail.com, ${ }^{2}$ roman_vitaliy@ukr.net, ${ }^{3}$ o_masnyak@ukr.net
}

Copyright (C 2017 by author and the journal "Automation technological and business - processes". This work is licensed under the Creative Commons Attribution International License (CC BY). http://creativecommons.org/licenses/by/4.0/

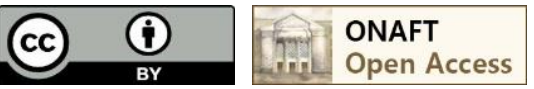

Анотація: В даній роботі авторами проведено дослідження ряду параметрів налаштовування CFD-програми Flow Simulations CAПP SolidWorks для підвищення ефективності моделювання ультразвукових витратомірів та витратомірів змінного перепаду тиску. За результатами роботи авторами запропоновано критерій точності відтворення масової витрати засобами СFD-моделювання та визначено діапазони значень параметрів налаштування CFD-програми Flow Simulations CAПP SolidWorks: вибрано оптимальний тип граничних умов на вході $i$ виході трьохвимірного макету вимірювальної ділянки трубопроводу з витратоміром певного типу; місие встановлення вхідного перерізу витратоміра; мінімально-достатнє значення рівня дроблення базової розрахункової сітки; відстань між твірними модифікованої сітки тривимірного макету. Запропоновані авторами рекомендації дають можливість забезпечити відтворення масової витрати під час моделювання газодинамічних явищ у розглянутих витратомірах з похибкою, щзо не перевищує $1 \%$, при мінімально можливій тривалості розв'язування моделі. Це дозволяє підвищити ефективність моделювання витратомірів за допомогою CFD-nрограми Flow Simulations CAПP SolidWorks. Результати роботи особливо актуальні при використанні засобів обчислювальної гідродинаміки для проведення обмежених за часом навчальних занять студентів технічних спеціальностей, зокрема в галузі автоматизаиії та комп'ютерно-інтегрованих технологій. Наведені авторами роботи рекомендаиії щяодо програмних налаштування Flow Simulations CAПP SolidWorks можуть бути інтерпретовані як для розглянутої, так $i$ інших CFD-програм що застосовуються для вирішення наукових прикладних задач ультразвукової витратометрії та витратомірів змінного перепаду тиску. 
Abstract: In this paper, the authors conducted study of a number of parameters configuring the CFD-program Flow Simulations of the CAD SolidWorks for increasing the efficiency of modelling of ultrasonic flowmeters and orifice flowmeters. According to the results of the work, the authors proposed criterion for the accuracy of mass flow reproduction by means of CFD simulation and the ranges of CFD-program Flow Simulations parameters setup of the CAD SolidWorks: the optimal type of boundary conditions at the inlet and outlet of the three-dimensional layout of the measuring section of the pipeline with a flow meter of a certain type is selected; location of the inlet section of the flowmeter; minimum-sufficient value of the level of fragmentation of the basic simulation grid; the distance between the creator modified grid of a three-dimensional layout. The recommendations suggested by the authors provide an opportunity to provide a reproduction of mass flow during the modelling of gas-dynamic phenomena in the considered flow meters with an error of not more than $1 \%$, with the minimum possible duration of the model's solution. This allows you to improve the efficiency of simulations of flowmeters using the CFD-program Flow Simulations of the CAD SolidWorks. The results of the work are especially relevant when using computational fluid dynamics for conducting time-limited training courses for students of technical specialties, in particular in the field of automation and computer-integrated technologies. The recommendations given by the authors of the work on the software settings of CFD-program Flow Simulations of the CAD SolidWorks can be interpreted for both the considered and other CFD-programs that are used to solve scientific applications of ultrasonic flowmeters and orifice flowmeters.

Ключові слова: обчислювальна гідродинаміка; тривимірний макет; витратомір; масова витрата; CFD-моделювання.

Keywords: computational fluid dynamics; three-dimensional layout; flowmeter; mass flow; CFD-simulation.

Мета дослідження та огляд наукових робіт

Для вирішення дослідницьких задач в галузі витратометрії застосовують два методи: експериментальний (із застосуванням витратовимірювальних установок та зразкових засобів вимірювання) та комп'ютерний (використовуючи сучасну комп'ютерну техніку та спеціальне програмне забезпечення) [1]. Зважаючи на складність реалізації та значні часові затрати експериментального методу, в наш час активно розвивається комп'ютерний метод [1-7] на базі методів обчислювальної гідродинаміки (Computational Fluid Dynamics, CFD) [8-10].

Слід відзначити, що комп'ютерний метод у поєднанні із результатами експериментів дає можливість отримати достовірні результати досліджень. Зокрема, цим методом досліджують вплив газодинамічних явищ у вимірювальних трубопроводах (ВТ) складних конфігурацій (що не охоплені у повній мірі експериментом [1, 2]) на вимірюване значення витрати. У науково-технічній літературі представлено результати таких досліджень для витратомірів змінного перепаду тиску [7] та ультразвукових витратомірів [4]. Додатковою перевагою застосування комп'ютерного методу, є суттєво нижча вартість комп'ютерної техніки, в порівнянні з вартістю обладнання для проведення експериментальних досліджень.

Попри зручність застосування комп'ютерного методу, для отримання достовірних результатів моделювання необхідно мати адекватну модель досліджуваного об'єкту (процесу), а також правильно сформувати умови розв'язування моделі. Застосування програмних пакетів, які реалізують методи CFD-моделювання, дає можливість побудувати модель об'єкту. Однак залишаються невирішеними ряд завдань, які виникають при налаштуванні CFDпрограм та визначенні умов моделювання. Зокрема, необхідно вирішити такі завдання:

1) обрати критерій точності відтворення витрати засобами CFD-моделювання;

2) визначити діапазони значень параметрів налаштування CFD-програми, за яких досягається необхідна точність відтворення витрати при мінімально можливій тривалості розв'язування моделі, тобто які забезпечують вищу ефективність моделювання.

Авторами поставлено за мету вирішити ці завдання для моделей витратомірів, реалізованих в CAПP SolidWorks, i3 застосуванням підпрограми для CFD-моделювання Flow Simulations.

Етапи дослідження

Процедура моделювання витратомірів із застосуванням CAD/CFD-програмних засобів передбачає виконання трьох послідовних етапів [4, 8]:

1. Підготовчий етап: з використанням САПР SolidWorks формують тривимірний макет прямолінійної ділянки ВТ із встановленим в ній первинним перетворювачем витратоміра (далі по тексту макет). На рис.1 показано фрагменти такого макету при дослідженні витратоміра змінного перепаду тиску (рис.1, а) та макету двоканального ультразвукового витратоміра (рис.1, б).

В цій роботі досліджено параметри налаштування CFD-програми Flow Simulations для макету ВТ без чутливих елементів витратомірів. Геометричні характеристики досліджуваного макету зображено на рис.2, а. Завершальним кроком даного етапу, є процес дискретизації - поділ макету на області розрахунку у вигляді базової розрахункової сітки (див.рис. 2, б).

2. Розрахунок параметрів потоку: за допомогою CFD-програми Flow Simulations реалізують чисельне (дискретне) розв'язування системи рівнянь Нав'є-Стокса, що описують потік середовища замкнутому об'ємі твердотілої моделі [8, 10]. За результатами розв'язування отримують значення параметрів середовища (густини, тиску, температури, швидкості) в кожній точці розрахункової сітки. 
http://www.atbp.onaft.edu.ua/
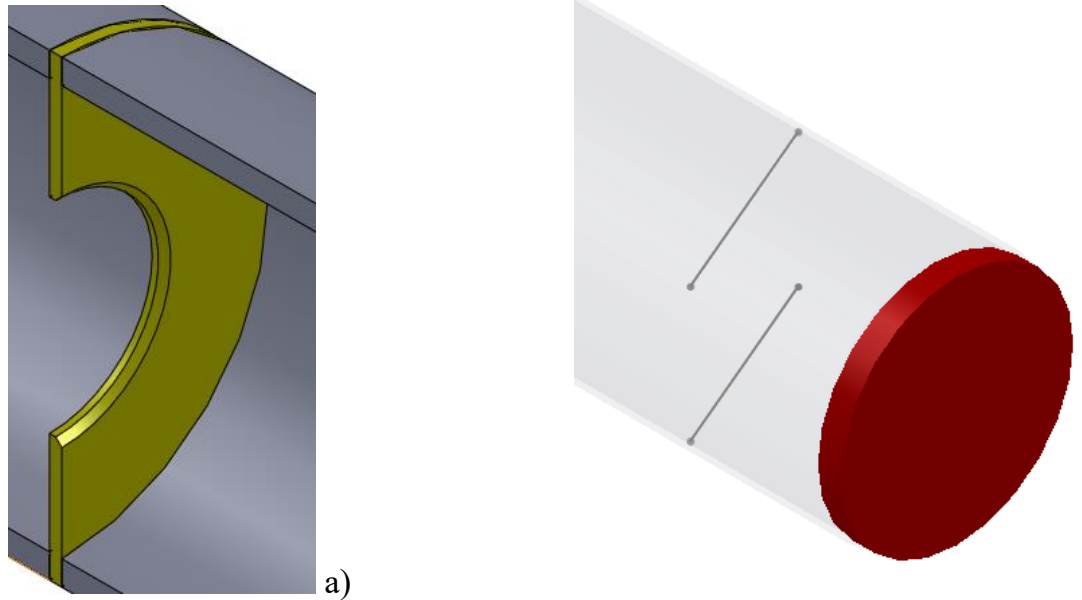

б)

Рис.1. Фрагменти макетів витратоміра за методом змінного перепаду тисків (а) та ультразвукового витратоміра (б), побудованих в САПР SolidWorks

Основними досліджуваними параметрами налаштування CFD-програми Flow simulations на цьому етапі є:

- тип граничних умов (Boundary Conditions, BC) на вході і виході макету;

- рівень дроблення базової розрахункової сітки (Level of Initial Mesh, s).

Решта параметрів налаштування необхідних для розв'язку системи рівнянь Нав'є-Стокса наведено в табл. 1.

Параметр налаштування CFD-програми - початкові умови (Initial Conditions, IC) залишаються незмінними (по замовчуванню), оскільки в даному випадку вирішується стаціонарна задача.

3. Опрацювання та аналіз результатів: за результатами розрахунку отримують масив значень основних параметрів потоку (швидкість, тиск, температура, густина) для всієї множини точок розрахункової сітки. Цей масив відтворює газодинамічні явища, які відбуваються в моделі і $є$ предметом подальшого аналізу.

Основними досліджуваними параметрами налаштування CFD-програми на цьому етапі є параметри, які активують після закінчення моделювання і які призначені тільки для візуалізації результатів моделювання:

- місце відбору (координати розташування поперечного перерізу ВТ, $l$ ) значень параметрів потоку;

- кількість точок в поперечному перерізі ВТ $(n)$.

Для опрацювання та аналізу результатів моделювання авторами застосовано пакет MATLAB 7.9.0 (R2009b). Bci три етапи виконані на комп’ютері з такими технічними характеристиками: CPU (Intel(R) Core(TM) i5-2450M CPU, 2.50 GHz, 2 активні ядра, 4 логічні процесори), пам'ять (DDR3, 6.0 ГБ), відео-система (Intel HD Graphics 3000 (GT2+), 2108 МБ).

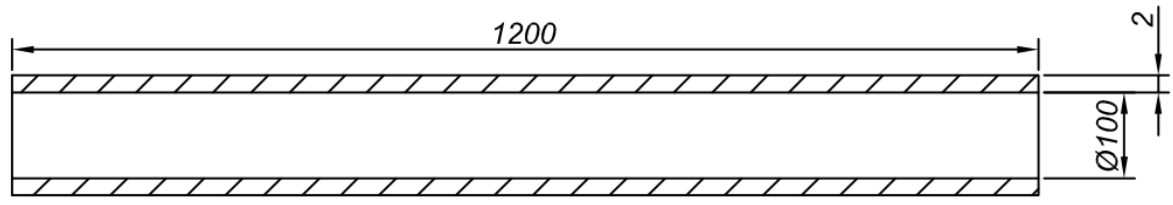

a)

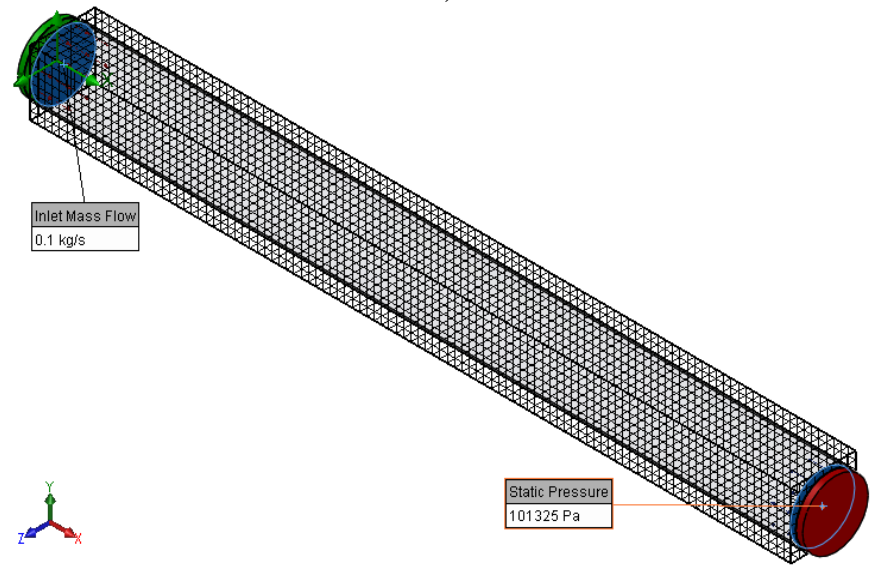

б)

Рис.2. Досліджуваний макет побудований в САПР SolidWorks:

а) геометричні характеристики макету; б) базова розрахункова сітка макету 
Таблиця 1 - Параметри налаштування Flow Simulations

\begin{tabular}{|c|c|}
\hline Тип задачі & внутрішня (internal) \\
\hline Тип середовища & повітря (air, gases) \\
\hline Температурні умови & адіабатична стінка \\
\hline Шорсткість & 0 мікрон \\
\hline Модель турбулентності & $\mathrm{k}-\varepsilon[3]$ \\
\hline Додаткове подрібнення сітки & так \\
\hline
\end{tabular}

Як критерій точності відтворення витрати засобами CFD-моделювання для вирішення задач витратометрії, вибрано відносну похибку розрахунку масової витрати $\delta_{q m}$ в $i$-му перерізі макету за результатами моделювання. Значення похибки $\delta_{q m}$ пропонується обчислювати за формулою [5]:

$$
\delta_{q m}(i)=\frac{q m_{C F D}(i)-q m_{B C}}{q m_{B C}} \cdot 100
$$

де: $q m_{B C}$ - масова витрата як гранична умова; $q m_{C F D}(i)$ - масова витрата в $i$-му перерізі макету, розрахована за рівнянням витрати того чи іншого методу вимірювання на основі результатів CFD-моделювання. В цій роботі для розрахунку значень витрати $q m_{C F D}(i)$ обрано так звану узагальнену швидкісну формулу масової витрати [6]:

$$
q m_{C F D}(i)=\frac{\pi d^{2}}{4} \cdot \frac{\sum_{j=1}^{n} v_{C F D}(j)}{n} \cdot \frac{\sum_{j=1}^{n} \rho_{C F D}(j)}{n},
$$

де: $v_{C F D}(j), \rho_{C F D}(j)$ - швидкість та густина потоку в $j$-тій точці $i$-го перерізу макету; $n$ - кількість точок $i$-го перерізу макету. У цій роботі результат відтворення витрати вважається задовільним, якщо значення похибки $\delta_{q m}$ не перевищують $\pm 1 \%$.

Результати дослідження

Розглянемо детальніше вплив названих вище параметрів налаштування CFD-програми Flow Simulations на точність відтворення витрати (похибку $\delta_{q m}$ ).

Згідно $[8,9]$ макети типу "труба" для внутрішніх задач повинні мати заглушки з обох боків. Це необхідно для чіткого відокремлення розрахункової області від навколишнього середовища. Для перевірки відсутності протікань (нещільності прилягання заглушок) використовується опція Check Geometry [9]. Якщо макет сформований 3 помилками, опція Check Geometry формує повідомлення про нульовий об'єм аналізованого макету. В протилежному випадку опція визначить числове значення об'єм макету відмінне від нуля. На створених заглушках макету задають граничні умови одного з наступних видів [8]: тиск (pressure), масова витрата (mass flow), об' ємна витрата (volume flow rate), швидкість (velocity), число Маха (Mach number). Крім цього, на заглушках вказують напрям потоку: inlet (вхід), outlet (вихід).

В результаті постає питання налаштувати перший параметр CFD-програми - обрати тип граничних умов на вході $\mathrm{i}$ виході макету. Зважаючи на те, що критерієм є відносна похибка відтворення масової витрати, авторами запропоновано використовувати як граничні умови масову витрату (mass flow; 0,1 kg/s) та статичний тиск (static pressure; $101325 \mathrm{~Pa}$ ). Вибір тиску як другої граничної умови обумовлений тим, що в парі 3 швидкісною характеристикою потоку (масова витрата, швидкість потоку) слід застосовувати один із потенціальних параметрів (тиск) [8].

Для візуалізації впливу типу граничних умов на похибку $\delta_{q m}$ згідно формули (1), авторами отримано результати CFD-моделювання параметрів потоку та похибки відтворення витрати $\delta_{q m}$ в 13 -ти поперечних перерізах макету (див. рис.3, 4). Перерізи рівномірно розміщені один відносно одного по всій довжині макету 3 кроком 0,1 м. Дослідження виконано при максимальному $(s=8)$ рівні подрібнення базової розрахункової сітки.

Враховуючи результати досліджень представлені на рис.3, вибір граничних умов вхідна масова витрата-вихідний статичний тиск або вхідний статичний тиск-вихідна масова витрата в значній мірі не впливає на результати відтворення масової витрати $\left(\delta_{q m}<1 \%\right)$. В подальших дослідженнях авторами обрано за основу граничні умови типу вхідна масова витрата-вихідний статичний тиск. 
Автоматизація технологічних і бізнес-процесів Volume 10, Issue 4 /2017 http://www.atbp.onaft.edu.ua/
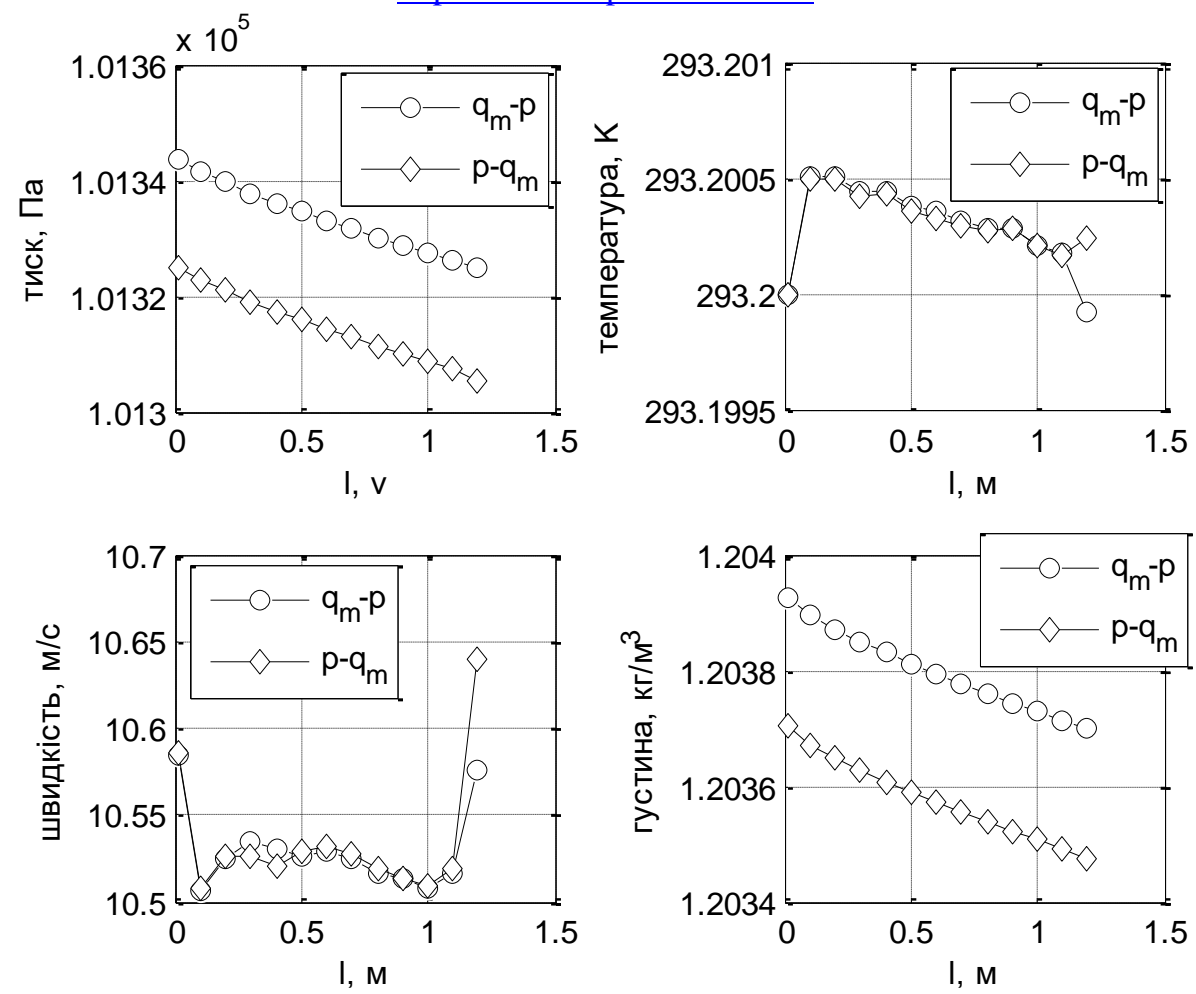

Рис.3. Розподіл усереднених по перерізу параметрів середовища вздовж макету для граничних умов: qm-p - вхідна масова витрата-вихідний статичний тиск; p-qm - вхідний статичний тиск-вихідна масова витрата
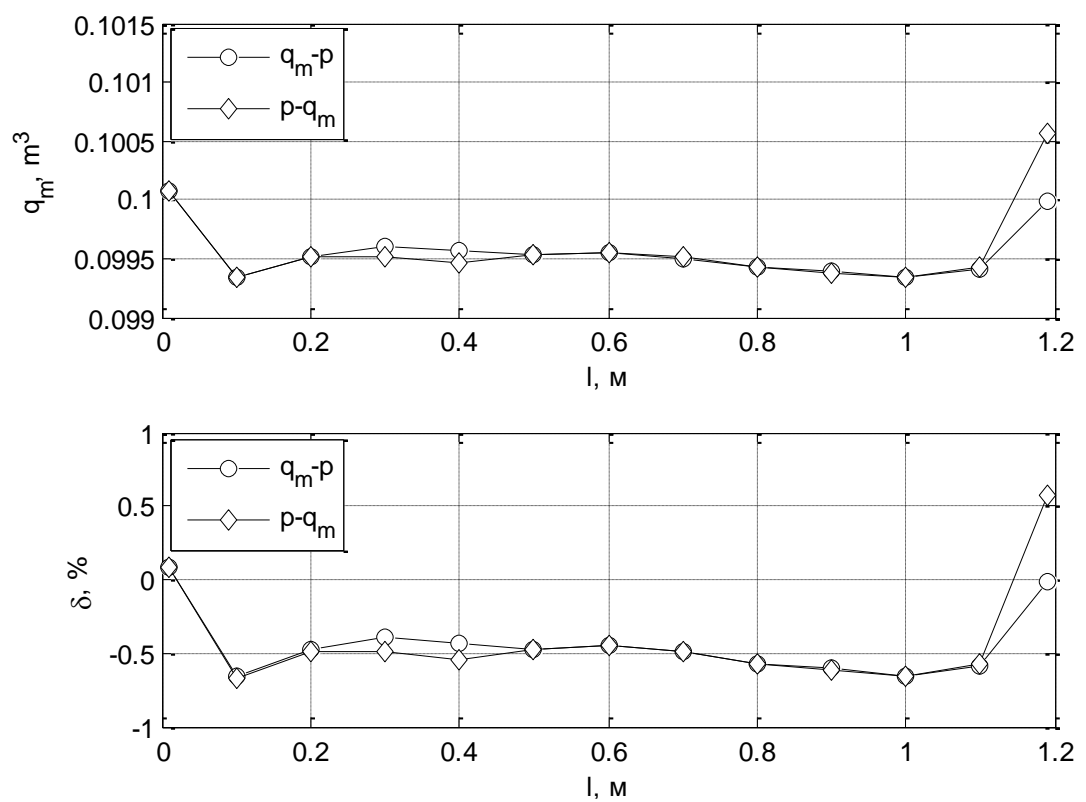

Рис.4. Розподіл значень масової витрати qтсғD та похибки $\delta_{q m}$ вздовж макету для граничних умов: qm-p - вхідна масова витрата-вихідний статичний тиск; p-qm - вхідний статичний тиск-вихідна масова витрата

Згідно з законом збереження маси масова витрата потоку, обчислена за формулою (2), повинна бути однаковою по всій довжині макету. Однак точність відтворення цього закону під час CFD-моделювання залежить від параметрів моделювання. Тому важливо так задати параметри моделювання та вибрати місце розташування аналізованих перерізів, щоб значення витрати $q m_{C F D}(i)$ якомога точніше співпадало із значенням витрати $q m_{B C}$. Це особливо важливо під час дослідження витратомірів в умовах спотворень структури потоку, коли значення витрати qm $C F D(i)$ використовують як зразкове. Для цього доцільним $є$ визначити місце відбору значень параметрів потоку для відтворення витрати.

Аналізуючи наведені на рис.3, 4 результати CFD-моделювання, можна стверджувати, що координату перерізу $l$ для 
http://www.atbp.onaft.edu.ua/

відбору значень параметрів потоку для відтворення витрати рекомендується обирати в межах прямолінійної ділянки макету на віддалі 1D від його заглушок.

В CFD-модулі Flow Simulations параметр налаштовування рівень дроблення базової розрахункової сітки має діапазон значень від $s=1 \ldots 8$ [8,9]. Він визначає розмір елементарної комірки базової розрахункової сітки. Чим вище $s$, тим густішою буде базова розрахункова сітка, тобто 3 меншими комірками, що дозволяють краще врахувати особливості геометрії макету, а отже, точніше відтворити розподіл параметрів потоку. Зрозуміло, що збільшення $s$ вимагає більше оперативної пам'яті та процесорного часу комп'ютера, на якому відбувається моделювання. Тому, особливо важливим є визначити мінімально-достатнє значення $s$. Для дослідження вибрано чотири різні значення параметра $s: 5$ (згідно $[8,9]$ вважається достатнім), 6, 7 та 8.

Результати CFD-моделювання параметрів потоку в поперечному перерізі $(l=0,6$ м) при різних рівнях дроблення базової розрахункової сітки наведено в табл.2.

Таблиця 2 - Усереднені по перерізу (I=0,6 м) параметри середовища

\begin{tabular}{|c|c|c|c|c|}
\hline$s$ & 5 & 6 & 7 & 8 \\
\hline CPU time, год:хв.:сек. & $0: 1: 44$ & $0: 5: 34$ & $0: 33: 37$ & $1: 05: 18$ \\
\hline швидкість, м/с & 10,1437 & 10,5319 & 10,5115 & 10,5264 \\
\hline густина, кг/м ${ }^{3}$ & 1,2038 & 1,2038 & 1,2038 & 1,2038 \\
\hline$q m_{C F D}, \mathrm{M}^{3} / \mathrm{c}$ & 0,0959 & 0,0995 & 0,0993 & 0,0995 \\
\hline$\delta_{q m}, \%$ & $-4,0930$ & $-0,4233$ & $-0,6163$ & $-0,4754$ \\
\hline
\end{tabular}

Із табл. 2 видно, що при збільшенні значення s досягаємо значення критерію точності $\left(\delta_{q m}<1 \%\right)$ починаючи вже $3 s$ $=6$. Проте, збільшення $\mathrm{s}$ призводить до суттєвого зростання тривалості моделювання $(C P U$ time $)-$ часу для проведення комп'ютером розрахунку значень параметрів у вузлах сітки. В умовах обмеженості часу (наприклад застосування цього підходу студентами в межах однієї академічної години) тривалість розрахунку має вкрай важливе значення. Тому, авторами рекомендовано обирати за мінімально-достатнє значення параметра $s=6$.

Для реалізації третього етапу комп'ютерних досліджень в CFD-програми Flow Simulations iснує зручна опція Point Parameters. Вона дозволяє зібрати (point picking) в один excel-файл масив значень параметрів потоку в потрібному перерізу макету (див. рис.5). Для цього необхідно:

1) обрати одну із трьох координат розташування перерізу (x-, y- або z-площина) і задати відстань на якій він буде розміщений відносно початку координат (plane position);

2) обрати метод збору (по точках - one by one або по сітці - grid) значень параметрів потоку; в даній роботі використано метод збору по сітці;

3) якщо вибрано метод збору по сітці, то необхідно налаштувати сітку (define grid by) вибравши один із двох запропонованих методів (задавши кількість точок сітки - number of points або задавши відстань між твірними сітки spacing, $b$ ).
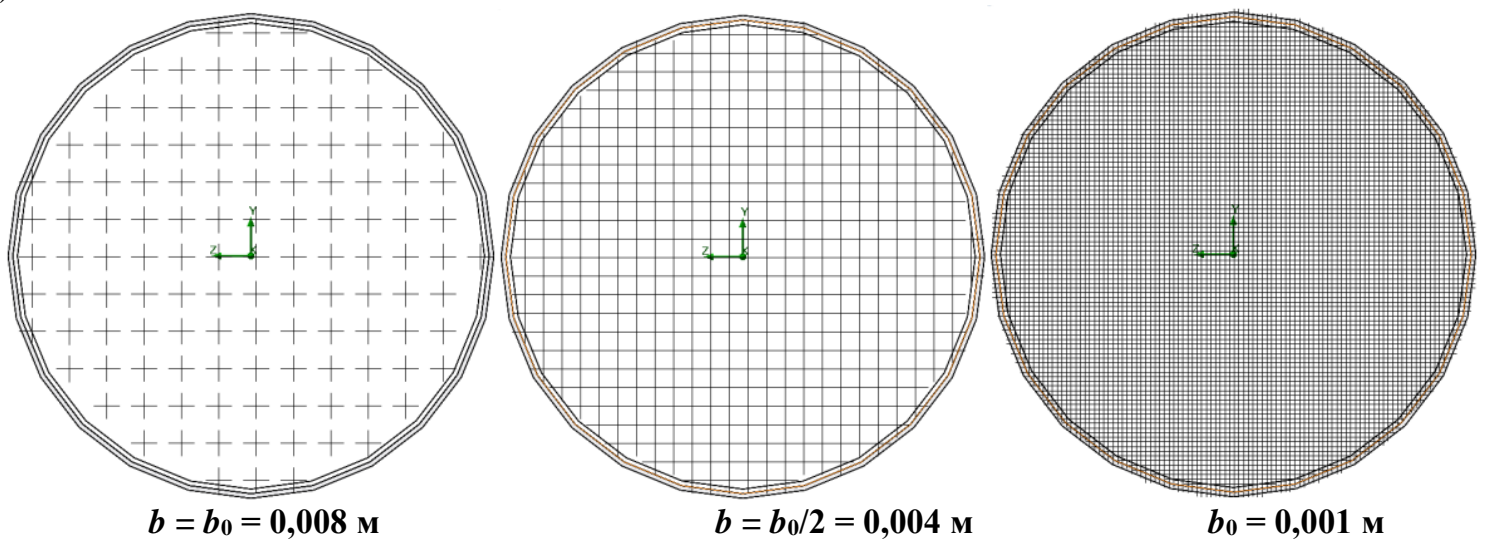

Рис.5. Вигляд модифікованої сітки в поперечному перерізі макету $(l=0,6$ м) при різних значеннях параметру $b($ при $s=6)$

В даній роботі досліджено випадок коли сітка налаштовується задаванням відстані між лініями (spacing метод). В цьому випадку конкретні точки із параметрами потоку знаходяться на перетині ліній. Якщо параметр $b$ вибирається за замовчуванням $\left(b_{0}\right)$ то така сітка буде називатись базовою. В свою чергу кількість точок в базові сітці залежатиме від параметра $s$ та геометрії поперечного перерізу. В тому випадку коли користувач задає значення параметра $b$ відмінне 
http://www.atbp.onaft.edu.ua/

від $b_{0}$, така сітка буде називатись модифікованою $[8,9]$. Значення параметрів потоку в точках модифікованої сітки будуть визначатись як:

- розраховані програмою значення параметрів потоку (при однаковості координат розташування точок базової та модифікованої сітки);

- апроксимовані програмою значення параметрів потоку (коли точки модифікованої сітки не співпадають із точками базової сітки). В останньому випадку для визначення апроксимованих значень параметрів потоку в точці модифікованої сітки вибираються значення сусідніх їй точок базової сітки.

Для дослідження в роботі вибрано три значення параметру $b: b=b_{0} ; b=b_{0} / 2 ; b_{0}=0,001$ м. Вигляд сітки в поперечних перерізах для наведених значень параметра $b$ (при $s=6$ ) представлено на рис.5.

Результати аналізу сітки при різних значеннях параметра $b$ наведено в табл.3 та на рис.6.

Таблиця 3 - Результати аналізу розрахункової сітки

\begin{tabular}{|c|c|c|c|c|c|}
\hline$N$ & $s$ & 5 & 6 & 7 & 8 \\
\hline \multirow{3}{*}{1} & $b_{1}=b_{0}, \mathrm{M}$ & 0,01 & 0,008 & 0,005 & 0,004 \\
\hline & $n$, шт. & 80 & 121 & 314 & 488 \\
\hline & $\delta_{q m}, \%$ & $-4,0930$ & $-0,4233$ & $-0,6163$ & $-0,4754$ \\
\hline \multirow{3}{*}{2} & $b_{2}=b_{0} / 2, \mathrm{M}$ & 0,005 & 0,004 & 0,0025 & 0,002 \\
\hline & $n$, шт. & 314 & 488 & 1253 & 1945 \\
\hline & $\delta_{q m}, \%$ & $-3,4331$ & $-1,0322$ & $-0,5613$ & $-0,3528$ \\
\hline \multirow{3}{*}{3} & $b_{3}=0,001 \mathrm{M}$ & \multicolumn{4}{|c|}{0,001} \\
\hline & $n$, шт. & \multicolumn{4}{|c|}{7784} \\
\hline & $\delta_{q m}, \%$ & $-2,8467$ & $-0,9639$ & $-0,2592$ & $-0,3614$ \\
\hline
\end{tabular}

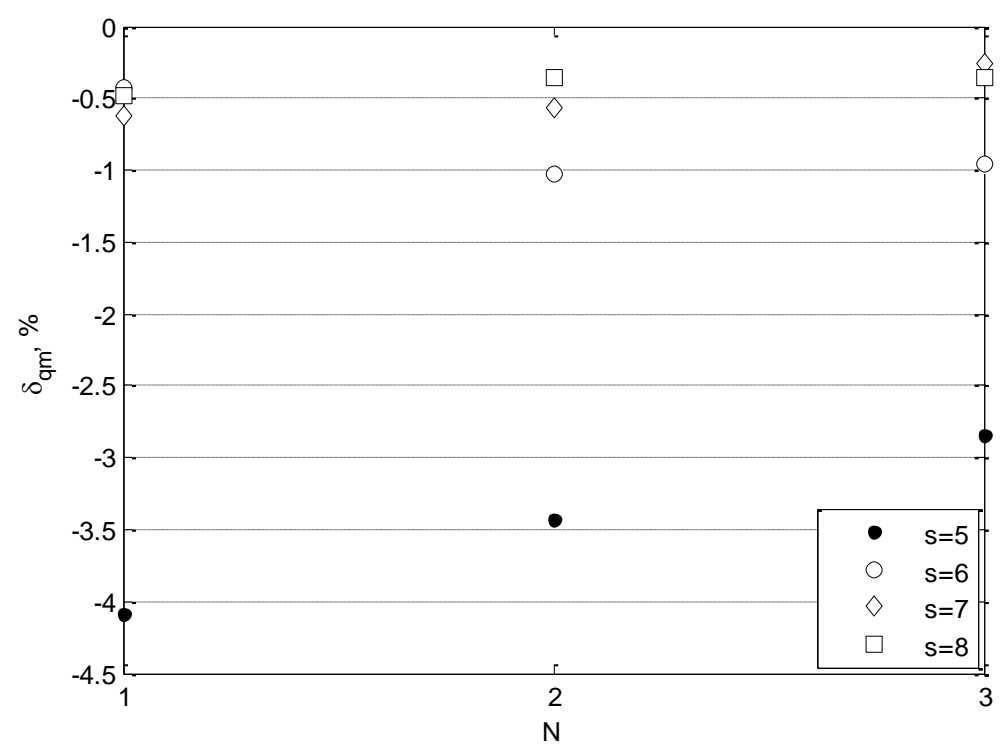

Рис.6. Залежність похибки відтворення витрати від значень параметру $N$ для різних значень $s$

Як видно з табл.3 та рис.6 подрібнення базової розрахункової сітки не призводить до суттєвого зменшення похибки відтворення витрати при значення параметра $s$ в діапазоні 6..8. Для випадку коли $s=5$ зменшення параметра $b$ призводить до зменшення цієї похибки, хоча за абсолютною величиною похибка все одно залишається значною $\left(\delta_{q m}=-2,8 \%\right)$. Як висновок, авторами рекомендується використовувати параметр $b$ по замовчування якщо $s \geq$ 6 і навпаки - зменшувати його при $s \leq 5$. Також необхідно наголосити, що збільшення параметра $b$ призводить до збільшення кількості інформації (кількості точок в перерізі) яку необхідно опрацювати, що потрібно брати до уваги при обмежених технічних ресурсах комп’ютера та часу на її обробку. 


\section{Висновки}

За результатами проведених досліджень сформовано рекомендації щодо параметрів налаштовування CFDпрограми Flow Simulations під час моделювання потоків у витратомірах:

1) як тип граничних умов на вході/виході макету обирати вхідна масова витрата/вихідний статичний тиск;

2) за місце встановлення вхідного перерізу витратомірів $l$ обирати середину прямолінійної ділянки макету;

3) за мінімально-достатнє значення рівня дроблення базової розрахункової сітки $s$ обирати $s=6$;

4) формувати розрахункову сітку задаючи відстань між твірними сітки $b$ рівну:

- базовій $b=b_{0}$ якщо рівень дроблення $s \geq 6$;

- або $b<b_{0}$ якщо $s \leq 5$.

Виконання цих рекомендацій дає можливість забезпечити відтворення масової витрати під час моделювання газодинамічних явищ у витратомірах 3 похибкою, що не перевищує 1 \%, при мінімально можливій тривалості розв'язування моделі, тобто підвищити ефективність моделювання витратомірів за допомогою CFD-методів.

Література

[1] M. Turkowskia and P. Szuflenski, "New criteria for the experimental validation of CFD simulations", Flow Measurement and Instrumentation, vol.34, pp.1-10, 2013. doi: https://doi.org/10.1016/j.flowmeasinst.2013.07.003.

[2] C. Ruppel and F. Peters, "Effects of upstream installations on the reading of an ultrasonic flowmeter", Flow Measurement and Instrumentation, vol.15, pp.167-177, 2004. doi: https://doi.org/10.1016/j.flowmeasinst.2003.12.004.

[3] Фафурин В.А. Анализ параметров численных методов при расчете метрологических характеристик расходомеров на базе стандартной диафрагмы [Текст] / В.А. Фафурин и др. // Вестник Казанского технологического университета. - 2011. - Вып.23. - С.136-141.

[4] Пістун Є.П. Дослідження похибки ультразвукових витратомірів за умов спотвореної структури потоку на основі CFD-моделювання [Текст] / С.П. Пістун та ін. // Метрологія та прилади. - 2014. - Вип.4. - С.13-23.

[5] V. Roman and F. Matiko, "The criterion of efficiency CFD-modelling for the research of ultrasonic flowmeters", in International academic conference of young scientists "Electric power engineering and control systems", Lviv, 2016, pp.199-200.

[6] T. Tresch et al., "Presentation of optimized integration methods and weighting corrections for the acoustic discharge measurement", in International conference on hydraulic efficiency measurements, Milano, 2008, 14 p.

[7] Manish S. Shah et al., "Analysis of flow through an orifice meter: CFD simulation”, Chemical Engineering Science, vol. 71, pp. 300-309, 2012. doi: https://doi.org/10.1016/j.ces.2011.11.022.

[8] Алямовский A.A. SolidWorks. Компьютерное моделирование в инженерной практике [Текст] / А.А. Алямовский // СПб, РФ : БВХ-Петербург, 2005. - 800 с.

[9] J.E. Matsson, “An introduction to solidworks flow simulations 2010”, in SDC Publ., 2010, $297 \mathrm{p}$.

[10] F.M. White, "Fluid mechanics", in McGraw-Hill Publ., $7^{\text {th }}$ ed., 2009, 885 p.

\section{References}

[1] M. Turkowskia and P. Szuflenski, "New criteria for the experimental validation of CFD simulations", Flow Measurement and Instrumentation, vol. 34, pp. 1-10, 2013. doi: https://doi.org/10.1016/j.flowmeasinst.2013.07.003.

[2] C. Ruppel and F. Peters, "Effects of upstream installations on the reading of an ultrasonic flowmeter", Flow Measurement and Instrumentation, vol. 15, pp. 167-177, 2004. doi: https://doi.org/10.1016/j.flowmeasinst.2003.12.004.

[3] Fafurin V.A. Analiz parametrov chislennyh metodov pri raschete metrologicheskih harakteristik rashodomerov na baze standartnoj diafragmy [Text] / V.A. Fafurin i dr. // Vestnik Kazanskogo tehnologicheskogo universiteta. - 2011. vol.23. - pp.136-141.

[4] Pistun Ye.P. Doslidzhennia pokhybky ultrazvukovykh vytratomiriv za umov spotvorenoi struktury potoku na osnovi CFD-modeliuvannia [Text] / Ye. P. Pistun ta in // Metrolohiia ta prylady. - 2014. - vol.4. - pp.13-23.

[5] V. Roman and F. Matiko, "The criterion of efficiency CFD-modelling for the research of ultrasonic flowmeters", in International academic conference of young scientists "Electric power engineering and control systems", Lviv, 2016, pp.199-200.

[6] T. Tresch et al., "Presentation of optimized integration methods and weighting corrections for the acoustic discharge measurement", in International conference on hydraulic efficiency measurements, Milano, 2008, $14 \mathrm{p}$.

[7] Manish S. Shah et al., "Analysis of flow through an orifice meter: CFD simulation", Chemical Engineering Science, vol. 71, pp. 300-309, 2012. doi: https://doi.org/10.1016/j.ces.2011.11.022.

[8] Aljamovskij A.A. SolidWorks. Komp'juternoe modelirovanie v inzhenernoj praktike [Text] / A.A. Aljamovskij // SPb, RF : BVH-Peterburg Publ., 2005. - 800 p.

[9] J.E. Matsson, "An introduction to solidworks flow simulations 2010”, in SDC Publ., 2010, 297 p.

[10] F.M. White, "Fluid mechanics", in McGraw-Hill Publ., $7^{\text {th }}$ ed., 2009, 885 p. 